\title{
TUNA DAN CAKALANG (SUATU TINJAUAN: PENGELOLAAN POTENSI SUMBERDAYA DI PERAIRAN INDONESIA)
}

\author{
Ahmad Talib* \\ Staf Pengajar FAPERTA UMMU-Ternate, Email: madoks75@yahoo.co.id
}

\begin{abstract}
ABSTRAK
Pengelolaaan sumberdaya ikan merupakan suatu aspek yang sangat menonjol disektor perikanan dan ketidak mampuan dalam pengelolaan sumberdaya ikan disektor perikanan. Tujuan penelitian ini adalah Untuk melihat sejauhmana potensi sumberdaya ikan tuna dan cakalang di perairan Indonesia. Metode penelitian yang digunakan dalam penelitian ini adalah studi kepustakaan. Hasil penelitian ini menunjukkan bahwa sumberdaya ikan yang tersedia cukup melimpah namun diperlukan ketrampilan dan pengelolaan sumberdaya dengan mempertimbngkan berbagai aspek-aspek yang harus yaitu aspek teknologi, sumberdaya manusia, bio-teknologi, aspek sosial dan aspek ekonomi sedangkan untuk pengelolaan sumberdaya ikan diperlukan manajamen untuk mengadakan koordinasi dengan sejumlah aktivitas yang meliputi planning, organizing, actuating, dan controlling.
\end{abstract}

Kata Kunci : Pengelolaan, potensi sumberdaya ikan tuna dan cakalang, perairan Indonesia

\section{PENDAHULUAN}

1.1. Latar Belakang

Indonesia sebagai negara kepulauan memiliki 18.306 pulau yang dipersatukan oleh laut dengan panjang garis pantai $81.000 \mathrm{~km}$ terpanjang kedua di dunia setelah Kanada, dengan bentang wilayah Indonesia dari ujung barat (Sabang) sampai Timur (Merauke) setara dengan London sampai Bagdad, Bentang ujung Utara (Kep. Satal) dan Selatan (Pulau Rote) setara dengan jarak Jerman sampai dengan AlAjazair, mempunyai potensi yang sangat besar dan mengandung kurang lebih 7000 species ikan.

Potensi sumberdaya tersebut ada yang dapat diperbaharui (renewable resources) seperti sumberdaya perikanan (perikanan tangkap, budidaya, industri pengolahan, bioteknologi), mangrove, gelombang energi, pasang surut, angin dan OTEC (Ocean Thermal Energy Conversion) dan energi yang tidak dapat diperbaharui (non-renewable resources) seperti sumberdaya minyak dan gas bumi serta mineral. Selain itu juga terdapat potensi lain yaitu jasa lingkungan kelautan yang dapat dikembangkan untuk pembangunan ekonomi nasional seperti pariwisata bahari, industri maritim dan jasa angkutan (Makur, 2004).

Potensi lestari sumberdaya ikan laut diperkirakan sebesar 6.4 juta ton per tahun dengan jumlah tangkapan yang diperbolehkan (JTB) sebesar 5.12 juta ton per tahun atau sekitar $80 \%$ dari potensi lestari, dan baru dimanfaatkan sebesar 4 juta ton (pada th 2002, atau baru $78.13 \%$ ). Potensi lain yaitu potensi pengembangan budidaya laut seluas 2 juta ha dengan volume 46.73 juta ton per tahun terdiri dari budidaya ikan (kakap, kerapu, gobia), udang, budidaya moluska (kerang-kerangan, mutiara dan teripang) dan budidaya rumput laut. Potensi tersebut baru termanfaatkan sekitar 0.7 juta ton per tahun. Potensi perikanan air tawar terdiri dari perairan umum seluas 550.000 ha dengan produksi 356.020 ton/tahun, kolam air tawar 805.700 ton/tahun dan mina padi sawah sebesar 233.400 ton/tahun (Dahuri, 2004).

Sejak dicanangkannya Program Revitalisasi Pertanian, Perikanan dan Kehutanan oleh Presiden Republik Indonesia pada tanggal 11 Juni 2005 maka dimulainya upaya untuk mewujudkan keunggulan kompetitif yang dibangun atas keunggulan 
komparatif berupa kekayaan sumberdaya alam yang dikelola dan diusahakan dengan menerapkan ilmu pengetahuan dan teknologi (IPTEK) serta manajemen professional. Pada sektor perikanan khususnya perikanan tangkap, komoditas yang dikedepankan adalah perikanan tuna. Perikanan tuna merupakan salah satu primadona perikanan Indonesia. Hal tersebut mengingat kontribusi komoditas ini dalam perolehan devisa maupun pertumbuhan nilai eksportnya sangat signifikan. Pendapatan devisa hasil perikanan, kelompok tuna dan cakalang merupakan penghasil devisa kedua setelah udang. Program revitalisasi yang dikhususkan di Indonesia pada bidang perikanan tangkap dititik beratkan pada revitalisasi tuna yang meliputi meliputi (1) perbaikan fasilitas penanganan ikan di atas kapal dan di darat, (2) penerapan metode penangkapan dan penanganan ikan yang baik serta (3) peningkatan kelembagaan usaha perikanan tangkap (Malawa, 2006).

Pendataan revitalisasi perikanan tuna merupakan upaya untuk memacu keberhasilan sub sektor perikanan tangkap, khususnya komoditas tuna (tuna, cakalang dan tongkol) melalui peningkatan mutu hasil penangkapan. Mengacu pada kebijakan dan strategi merevitalisasi perikanan tuna, terdapat program-program yang dalam pelaksanaannya dilakukan secara sinergis bersama program reguler pada tahun 2006-2009.

Untuk melihat keberhasilan program revitalisasi tuna dan permasalahan dalam pendataan revitalisasi perikanan tuna meliputi (a) perbaikan fasilitas penanganan ikan di atas kapal dan di darat, (b) penerapan metoda penangkapan ikan dan penanganan ikan yang baik dan (c) peningkatan kelembagaan usaha perikanan tangkap. Salah satu tujuan program ini adalah pendataan dan penyajian data dan informasi statistik revitalisasi perikanan tuna, rehabilitasi, peningkatan, peningkatan sistem penanganan, mutu, nilai tambah, dan daya saing dan kualitas ikan tuna yang didaratkan di pelabuhan perikanan dan Unit Pengolah Ikan (UPI) (Anonimous, 2011).

\subsection{Tujuan Penulisan}

1. Untuk melihat sejauhmana potensi sumberdaya ikan tuna dan cakalang di perairan Indonesia.

2. Untuk melihat permasalahan yang timbul akibat pengelolaan sumberdaya ikan tuna dan cakalang yang belum dikelola secara maksimal.

\section{PEMBAHASAN}

\subsection{Sumberdaya Ikan Tuna dan Cakalang}

Jenis-jenis ikan pelagis besar yang terdapat di perairan Indonesia antara lain : ikan tuna yang meliputi: madidihang (Thnunnus albacores), tuna mata besar (Thunnus obesus), albacore (Thunnus alalunga) tuna sirip biru selatan (Thunnus maccoyii) tuna ekor panjang (Thunnus tonggol. Jenis ikan tuna kecil meliputi : ikan cakalang (katsuwonus pelamis) dan jenis ikan tongkol yang terdiri dari atas euthynnus affinis dan Auxis thazard.

Ikan pelagis besar tersebar dihampir semua wilayah pengeloaan perikanan dimana tingkat pemanfaatan berbeda-beda antar perairan. Menurut Direktur Jenderal Perikanan Tangkap (2005), bahwa beberapa wilayah pengelolaan antara lain Selat Malaka, Laut Jawa, Samudera Pasifik telah mengalami over Exploited di lain beberapa wilayah pengelolaan antara lain Laut Cina Selatan, Laut Flores, Laut Banda Seram, Laut Hindia masih pada tingkatan under exploited.

\subsection{Daerah dan Musim Penangkapan Tuna}

Ikan tuna biasanya hidup pada kedalamannya mencapai $\mathbf{1 0 . 0 0 0} \mathrm{m}$ di laut Banda yang merupakan salah satu daerah penangkapan ikan tuna (terutama ikan tuna mata besar) di kawasan timur Indonesia. Musim penangkapan di perairan Laut Banda mencapai puncaknya pada bulan November. Penyebaran ikan-ikan tuna di kawasan barat Indonesia terutama terdapat di Samudera Hindia. Di perairan ini terjadi percampuran antara perikana tuna lapisan dalam yang dieksploitasi dengan alat rawai tuna dengan perikana tuna permukaan yang dieksploitasi menggunakan alat tangkap pukat cincin, gillnet, tonda, dan payang.

Pemanfaatan sumberdaya ikan tuna secara umum dilakukan dengan menggunakan 
alat tangkap pancing tonda. Jenis ikan yang banyak tertangkap di wilayah ini adalah cakalang dan madidihang. Hasil analisis data produksi menyebutkan bahwa titik tertinggi terjadi pada bulan Oktober. Ini berarti, puncak musim penangkapan ikan pelagis besar dengan menggunakan alat tangkap tonda di perairan barat Sumatera terjadi pada bulan Oktober. Data dan informasi musim penangkapan sumberdaya ikan pelagis besar untuk perairan Samudera Hindia di wilayah selatan Jawa dan Nusa Tenggara diperoleh dari basis penangkapan Pelabuhan Perikanan Nusantara Pelabuhan ratu (Jawa Barat), Pelabuhan Perikanan Nusantara Cilacap (Jawa Tengah), dan Pelabuhan Benoa (Bali).

Ikan tuna sirip biru adalah jenis ikan tuna yang punya nilai paling tinggi. Perairan Samudera Hindia di sebelah selatan Jawa, Bali, dan Nusa Tenggara merupakan daerah pemijahan dari jenis tuna ini. Ikan biasanya bermigrasi ke perairan selatan Jawa dan Bali, dan umumnya nelayan menangkap ketika berada dalam kondisi memijah pada November dan Januari. Tingginya nilai tuna sirip biru menyebabkan ikan ini menjadi target penangkapan terutama oleh armada Jepang, Taiwan, Korea, Selandia Baru,dan Australia.

\subsection{Teknologi Pengkapan Ikan Tuna}

Teknologi yang digunakan dalam pemanfaatan sumber daya tuna disesuaikan dengan sifat dan tingkah laku ikan sasaran. Tuna merupakan ikan perenang cepat yang bergerombol. Oleh karena itu, alat penangkap ikan yang digunakan haruslah yang sesuai dengan perilaku ikan tersebut. Ada lima macam alat penangkap tuna, yaitu rawai tuna, huhate, handline. pukat cincin, dan jaring insang. Rawai tuna (tuna longllne) Rawai tuna atau tuna longline adalah alat penangkap tuna yang paling efektif. Rawai tuna merupakan rangkaian sejumlah pancing yang dioperasikan sekaligus. Satu tuna longliner biasanya mengoperasikan 1.000 - 2.000 mata pancing untuk sekali turun. Rawai tuna umumnya dioperasikan di laut lepas atau mencapai perairan samudera.

Alat tangkap ini bersifat pasif, menanti umpan dimakan oleh ikan sasaran. Setelah pancing diturunkan ke perairan, lalu mesin kapal dimatikan. sehingga kapal dan alat tangkap akan hanyut mengikuti arah arus atau sering disebut drifting. Drifting berlangsung selama kurang lebih empat jam. Selanjutnya mata pancing diangkat kembali ke atas kapal. Umpan longline harus bersifat atraktif. misalnya sisik ikan mengkilat, tahan di dalam air, dan tulang punggung kuat. Umpan dalam pengoperasian alat tangkap ini berfungsi sebagai alat pemikat ikan. Jenis umpan yang digunakan umumnya ikan pelagis kecil, seperti lemuru (Sardinella sp.), layang (Decopterus sp.), kembung (Rastrelliger sp.), dan bandeng (Chanos chanos).

Huhate (pole and line) Huhate atau pole and line khusus dipakai untuk menangkap cakalang. Tak heran jika alat ini sering disebut "pancing cakalang". Huhate dioperasikan sepanjang siang hari pada saat terdapat gerombolan ikan di sekitar kapal. Alat tangkap ini bersifat aktif. Kapal akan mengejar gerombolan ikan. Setelah gerombolan ikan berada di sekitar kapal, lalu diadakan pemancingan.

Terdapat beberapa keunikan dari alat tangkap huhate. Bentuk mata pancing huhate tidak berkait seperti lazimnya mata pancing. Mata pancing huhate ditutupi bulu-bulu ayam atau potongan rafia yang halus agar tidak tampak oleh ikan. Bagian haluan kapal huhate mempunyai konstruksi khusus, dimodifikasi menjadi lebih panjang, sehingga dapat dijadikan tempat duduk oleh pemancing. Kapal huhate umumnya berukuran kecil. Di dinding bagian lambung kapal, beberapa $\mathrm{cm}$ di bawah dek, terdapat sprayer dan di dek terdapat beberapa tempat ikan umpan hidup. Sprayer adalah alat penyemprot air.

Pemancingan dilakukan serempak oleh seluruh pemancing. Pemancing duduk di sekeliling kapal dengan pembagian kelompok berdasarkan keterampilan memancing. Pemancing I adalah pemancing paling unggul dengan kecepatan mengangkat mata pancing berikan sebesar 50-60 ekor per menit. Pemancing I diberi posisi di bagian haluan kapal, dimaksudkan agar lebih banyak ikan tertangkap. Pemancing II diberi posisi di bagian lambung kiri dan kanan kapal. Sedangkan pemancing III berposisi di bagian buritan, umumnya adalah orang-orang yang 
baru belajar memancing dan pemancing berusia tua yang tenaganya sudah mulai berkurang atau sudah lamban. Hal yang perlu diperhatikan adalah pada saat pemancingan dilakukan jangan ada ikan yang lolos atau jatuh kembali ke perairan, karena dapat menyebabkan gerombolan ikan menjauh dari sekitar kapal.

Umpan yang digunakan adalah umpan hidup, dimaksudkan agar setelah ikan umpan dilempar ke perairan akan berusaha kembali naik ke permukaan air. $\mathrm{Hal}$ ini akan mengundang cakalang untuk mengikuti naik ke dekat permukaan. Selanjutnya dilakukan penyemprotan air melalui sprayer. Penyemprotan air dimaksudkan untuk mengaburkan pandangan ikan, sehingga tidak dapat membedakan antara ikan umpan sebagai makanan atau mata pancing yang sedang dioperasikan. Umpan hidup yang digunakan biasanya adalah teri (Stolephorus spp.).

Pancing ulur (handline) Handline atau pancing ulur dioperasikan pada siang hari. Konstruksi pancing ulur sangat sederhana. Pada satu tali pancing utama dirangkaikan 2-10 mata pancing secara vertikal. Pengoperasian alat ini dibantu menggunakan rumpon sebagai alat pengumpul ikan. Pada saat pemancingan, satu rumpon dikelilingi oleh lima unit kapal, masing-masing kapal berisi 3-5 orang pemancing. Umpan yang digunakan adalah ikan segar yang dipotong-potong. Hasil tangkapan utama pancing ulur adalah tuna (Thunnus spp.). Pukat cincin (purse seine) Pukat cincin atau purse seine adalah sejenis jaring yang di bagian bawahnya dipasang sejumlah cincin atau gelang besi. Dewasa ini tidak terlalu banyak dilakukan penangkapan tuna menggunakan pukat cincin, kalau pun ada hanya berskala kecil.
Pukat cincin dioperasikan dengan cara melingkarkan jaring terhadap gerombolan ikan. Pelingkaran dilakukan dengan cepat, kemudian secepatnya menarik purse line di antara cincin-cincin yang ada, sehingga jaring akan membentuk seperti mangkuk. Kecepatan tinggi diperlukan agar ikan tidak dapat meloloskan diri. Setelah ikan berada di dalam mangkuk jaring, lalu dilakukan pengambilan hasil tangkapan menggunakan serok atau penciduk. Pukat cincin dapat dioperasikan siang atau malam hari. Pengoperasian pada siang hari sering menggunakan rumpon atau payaos sebagai alat bantu pengumpul ikan. Sedangkan alat bantu pengumpul yang sering digunakan di malam hari adalah lampu, umumnya menggunakan lampu petromaks. Gafa et al. (1987) mengemukakan bahwa payaos selain berfungsi sebagai alat pengumpul ikan juga berfungsi sebagai penghambat pergerakan atau ruaya ikan, sehingga ikan akan berada lebih lama di sekitar payaos. Uktolseja (1987) menyatakan bahwa payaos dapat menjaga atau membantu cakalang tetap berada d lokasi pemasangannya selama 340 hari.

Jaring insang (gillnet) Jaring insang merupakan jaring berben berbentuk empat persegi panjang dengan ukuran mata yang sama di sepanjang jaring. Dinamakan jaring insang karena berdasarkar cara tertangkapnya, ikan terjerat di bagian insangnya pada mata jaring. Ukuran ikan yang tertangkap relatif seragam. Pengoperasian jaring insang dilakuka secara pasif. Setelah diturunkan ke perairan, kapal dan alat dibiarkan drifting, umumnya berlangsung selama 2-3 jam. Selanjutnya dilakukan pengangkat jaring sambil melepaskan ikan hasil tangkapan ke palka (Rafik, 2011). Kisaran suhu ikan cakalang dan tuna dapat dilihat pada Tabel 1.

Tabel 1. Kisaran Suhu Penyebaran dan Penangkapan Serta Lapisan Renang Ikan Cakalang dan Beberapa Jenis Tuna

\begin{tabular}{lccc}
\hline \multirow{2}{*}{ Jenis Ikan } & \multicolumn{2}{c}{ Kisaran Suhu ( C) } & Lapisan Renang \\
\cline { 2 - 3 } & Penyebaran & Penangkapan & $0-40$ \\
\hline Cakalang & $17-28$ & $19-23$ & $50-300$ \\
Bluefine & $12-25$ & $15-22$ & $50-400$ \\
Mata Besar & $11-28$ & $18-22$ & $0-200$ \\
Madidihang & $18-31$ & $20-28$ & $20-300$ \\
Albacore & $14-23$ & $15-21$ & \\
\hline
\end{tabular}

Sumber : ( Laevastu and Hela, 1970 dalam Simbolon, 2003) 
Kisaran suhu penyebaran dan penangkapan cakalang umumnya bervariasi sesuai dengan wilayah perairan. Ikan cakalang di Samudera Pasifik bagian timur ditemukan pada kisaran suhu permukaan laut (SPL) 17 - 30 ${ }^{\circ} \mathrm{C}$ dengan suhu optimum $20 \mathrm{C}-28{ }^{\circ} \mathrm{C}$ (Blackburn, 1965dalam Simbolon, 2003). (Gunarso, 1985 dalam Simbolon, 2003) menyatakan bahwa suhu perairan optimum untuk penangkapan cakalang di perairan Indonesia adalah 28 - $29{ }^{\circ} \mathrm{C}$. Adapun kisaran suhu yang optimum untuk penangkapan cakalang dan tuna pada berbagai perairan disajikan pada Table 2 .

\subsection{Sumberdaya Ikan Cakalang}

1). Daerah dan Musim Penangkapan Cakalang

Potensi cakalang di indonesia sebagian besar terdapat di perairan kawasan timur indonesia. Daerah penangkapan yang potensial bagi ikan tersebut di KTI terdapat di perairan Sulawesi Utara, Halmahera, Maluku dan Irian Jaya dengan basis penangkapan masing-masing di Bitung, Ternate, Ambon dan Sorong. Wilayah yang memiliki potensi cakalang di kawasan barat indonesia terdapat di perairan selatan Jawa Barat (Pelabuhan Ratu), Sumatera Barat dan Aceh (Monintja et al, 2001 dalam Simbolon, 2003).

Table 2. Kisaran Suhu Perairan Untuk Penangkapan Cakalang dan Tuna Menurut Wilayah Perairan

\begin{tabular}{llcll}
\hline No & Wilayah Perairan & Suhu optimum $(C)$ & Sumber & Keterangan \\
\hline 1 & Pasifik timur laut & $20-26$ & Blackburn, 1965 & Cakalang dan Tuna \\
2 & Pasifik Tenggara & $20-28$ & Blackburn, 1965 & Cakalang dan Tuna \\
3 & Pasifik Barat laut & $20-28$ & Blackburn, 1965 & Cakalang dan Tuna \\
4 & New Zeland & $17-23$ & Blackburn, 1965 & Cakalang dan Tuna \\
5 & Papua New guinea & $28-30$ & Blackburn, 1965 & Cakalang dan Tuna \\
6 & Indonesia & $28-29$ & Blackburn, 1965 & Cakalang dan Tuna \\
\hline
\end{tabular}

Sumber: (Monintja et al, 2001 dalam Simbolon, 2003).

Tabel 3. Puncak Musim Penangkapan Cakalang dan Tuna Menurut Wilayah Perairan

\begin{tabular}{lll} 
No. & Wilayah Perairan & \multicolumn{1}{c}{ Puncak Musim } \\
\hline 1 & Sulawesi Utara - Tengah & Maret s/d Mei; Agustus s/d Nopember; April s/d Juni \\
2 & Halmahera & September s/d Oktober; Pebruari s/d April \\
3 & Maluku & September s/d Desember \\
4 & Irian Jaya & Pebruari s/d Juni; Agustus s/d Desember \\
5 & Pelabuhan ratu & Agustus s/d September \\
6 & Padang & Maret s/d Mei \\
7 & Aceh & Belum diperoleh informasi \\
\hline Sumber: & (Monintja et al, 2001 dalam Simbolon, 2003)
\end{tabular}

Musim penangkapan ikan cakalang di perairan indonesia pada umumnya dapat dilakukan sepanjang tahun, namun puncak musim penangkapan sering kali bervariasi menurut wilayah perairan, sebagai mana disajikan pada Tabel 3.

Alat yang digunakan nelayan untuk menangkap cakalang adalah Huhate yang hanya diijinkan pengoperasiannya di wilayah perairan tertentu dan ZEEI Laut Sulawesi dan ZEEI Samudera Pasifik (Direktorat Jenderal Perikanan Tangkap, 2005). Secara garis besarnya, cakalang mempunyai daerah penyebaran dan migrasi yang luas, yaitu meliputi daerah tropis dan sub tropis dengan daerah penyebaran terbesar terdapat disekitar perairan khatulistiwa. Daerah penangkapan merupakan salah satu faktor penting yang dapat menentukan berhasil atau tidaknya suatu operasi penangkapan. Dalam hubungannya dengan alat tangkap, maka daerah penangkapan tersebut haruslah baik dan dapat menguntungkan, Dalam arti ikan berlimpah, bergerombol, daerah aman, tidak jauh dari pelabuhan dan alat tangkap mudah dioperasikan. Lebih lanjut Paulus (1986), menyatakan bahwa dalam memilih dan menentukan daerah penangkapan, harus memenuhi syarat-syarat antara lain :

a. Kondisi daerah tersebut harus sedemikian rupa sehingga ikan dengan mudah datang dan berkumpul.

b. Daerahnya aman dan alat tangkap mudah dioperasikan.

c. Daerah tersebut harus daerah yang secara ekonomis menguntungkan. Hal ini tentu 
saja erat hubungannya dengan kondisi oseanografi dan meteorologist suatu perairan dan faktor biologi dari ikan cakalang itu sendiri.

2). Armada Penangkapan Ikan (Skipjack Pole and Line)

Skipjack pole and line adalah jenis kapal yang digunakan untuk menangkap ikan cakalang (Katsuwonus pelamis). Tipe kapal jenis ini memerlukan palka ikan, tangki untuk menyimpan umpan hidup serta system sirkulasi airnya, pipa-pipa dan pompa untuk memercikan air, tempat duduk untuk pemancing serta geladak kapal untuk tempat menjatuhkan ikan hasil pancingan. Jenis kapal yang digunakan dalam operasi penangkapan ikan cakalang adalah pole and line tipe skipjack fishing boat. Kapal ini memiliki persyaratan tertentu yaitu pada haluan kapal dibuat anjungan yang mencuat kedepan untuk tempat pemancingan (tempat duduk pemancing), memiliki bak tempat umpan hidup (live bait tank), tempat penyimpanan hasil tangkapan, mempunyai system penyemburan air/spoit (water pump) dan palka yang dapat menampung ikan hasil tangkapan.

Huhate (Skipjack Pole and Line) atau umumnya lebih dikenal dengan "pole and line" adalah cara pemancingan dengan menggunakan pancing yang Huhate (Skipjack Pole and Line) atau umumnya lebih dikenal dengan "pole and line" adalah cara pemancingan dengan menggunakan pancing yang dikhususkan untuk menangkap ikan cakalang yang banyak digunakan di perairan Indonesia.

Menurut Uktolseja et al (1989), penyebaran cakalang di perairan Indonesia meliputi Samudra Hindia (perairan Barat Sumatra, selatan Jawa, Bali, Nusa Tenggara), Perairan Indonesia bagian Timur (Laut Sulawesi, Maluku, Arafuru, Banda, Flores dan Selat Makassar) dan Samudra Fasifik (perairan Utara Irian Jaya).

Penangkapan dengan pole and line dapat menggunakan kapal motor (kapal motor khusus cakalang, tuna clipper), tetapi untuk nelayan-nelayan kecil biasanya menggunakan perahu dayung (rowing boat) yang biasanya disebut "Funai" dan atau "Rurehe". Ada keistimewaan-keistimewaan dalam penangkapan cakalang dengan huhate ini, yaitu pertama harus adanya umpan hidup (life bait fish), dan kedua ialah adanya bentuk kapal khusus (Subani dan Barus, 1989).

Huhate adalah jenis alat pancing penangkap ikan yang terdiri dari bambu sebagai joran/tongkat dan tali sebagai tali pancing. Pada tali pancing ini dikaitkan mata pancing yang tidak berkait. Penggunaan mata pancing yang tidak berkait dimaksudkan agar ikan yang ditangkap dapat mudah lepas (Direktorat Sarana Perikanan Tangkap, 2003).

Menurut Ayodhoya (1981), pole and line umum digunakan untuk menangkap ikan cakalang (Katsuwonus pelamis) sehingga dengan kata perikanan pole and line sering pengertian kita ke arah perikanan cakalang, sungguhpun dengan cara pole and line juga dilakukan penangkapan albacore, mackerel dan lain sebagainya.

3). Bentuk Kapal

Menurut Subani dan Barus (1989), bentuk kapal cakalang mempunyai beberapa pengkhususan, antara lain:

a. Di bagian atas dek kapal bagian depan terdapat plataran (plat form) dimana pada tempat tersebut para pemancing melakukan pemancingan.

b. Dalam kapal harus tersedia bak-bak untuk menyimpan ikan umpan hidup.

c. Kapal cakalang perlu dilengkapi dengan sistem semprotan air (water splinker system) yang dihubungkan dengan suatu pompa. Kapal cakalang yang umumnya digunakan mempunyai ukuran 20 GT dengan kekuatan 40 - 60 HP.

Kapal pole and line adalah kapal dengan bentuk yang stream line dan mempunyai olah gerak kapal yang lincah dan tergolong kapal yang mempunyai kecepatan service sedang yaitu diatas 10 knot dan gerakan stabilitas yang baik untuk mengejar segerombolan ikan, yakni kapal tersebut sambil olah gerak

\section{4). Persiapan Operasi Penangkapan Ikan}

Operasi penangkapan tentunya dimulai dari persiapan-persiapan terutama perbekalan dan perlengkapan, persiapan itu meliputi : bahan makanan, es, lampu, dan bahan bakar minyak, alat navigasi, persiapan mesin, persiapan pengaturan alat tangkap dan bahan lainnya (Sadhori, 1985). Selanjutnya persiapan 


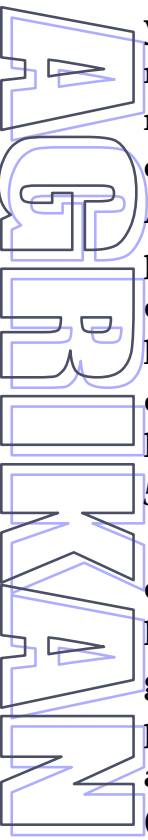

yang harus dilakukan di laut adalah mempersiapkan peralatan penangkapan yang menunjang keberhasilan penangkapan ikan cakalang serta penyediaan umpan hidup. Adanya faktor umpan hidup membuat cara penangkapan ini menjadi agak rumit. Hal ini disebabkan karena umpan hidup tersebut harus sesuai dalam ukuran dan jenis tertentu, disimpan, dipindahkan, dan dibawa dalam keadaan hidup (Malawa dan Sudirman, 2004).

5). Operasi Penangkapan Ikan

Operasi penangkapan dengan huhate dilakukan dengan cara mencari dan memburu kelompok ikan cakalang. Pencarian gerombolan ikan dilakukan oleh seorang pengintai yang tempatnya biasa berada di anjungan kapal dan menggunakan teropong (Mallawa dan Sudirman, 2004). Keberadaan ikan cakalang dapat dilihat melaui tanda-tanda antara lain: adanya buih atau cipratan air, loncatan ikan cakalang ataupun gerombolan burung- burung yang terbang menukik ke permukaan laut dimana gerombolan ikan berada. Setelah menemukan gerombolan ikan, yang harus diketahui adalah arah renang kemudian mendekati gerombolan ikan tersebut. Sementara pemancing sudah bersiap masing-masing pada sudut kiri, kanan, dan haluan kapal.

Pelemparan umpan dilakukan oleh boiboi setelah diperkirakan ikan telah berada dalam jarak jangkauan lemparan, kemudian ikan dituntun ke arah haluan kapal. Pelemparan umpan ini diusahakan secepat mungkin sehingga gerakan ikan dapat mengikuti gerakan umpan menuju haluan kapal. Pada saat pelemparan umpan tersebut, mesin penyemprot sudah dihidupkan agar ikan tetap berada di dekat kapal.

Pada saat gerombolan ikan berada dekat haluan kapal, maka mesin kapal dimatikan. Sementara jumlah umpan yang dilemparkan ke laut dikurangi, mengingat terbatasnya umpan hidup. Selanjutnya, pemancingan dilakukan dan diupayakan secepat mungkin mengingat kadang-kadang gerombolan ikan tiba-tiba menghilang terutama jika ada ikan yang berdarah atau ada ikan yang lepas dari mata pancing dan jumlah umpan yang sangat terbatas. Hal lain yang perlu diperhatikan pada saat pemancingan adalah menghindari ikan yang telah terpancing jatuh kembali ke laut. Hal ini akan mengakibatkan gerombolan ikan yang ada akan melarikan diri ke kedalaman yang lebih dalam dan meninggalkan kapal, sehingga mencari lagi gerombolan ikan yang baru tentu akan mengambil waktu. (Mallawa dan Sudirman, 2004).

\section{6). Teknik Penangkapan Ikan Cakalang}

Menurut Subani dan Barus (1989), penangkapan dengan pole and line dilakukan dengan terlebih dahulu mencari gerombolan cakalang. Untuk mendapatkan kawanan cakalang dapat dilakukan dengan cara berlayar kesana- kemari (manouvre), memperhatikan kawanan burung laut atau dapat diperoleh disekitar rumpon (payaos) yang telah dipasang (ditanam) lebih dulu. Pemancingan dilakukan dengan setiap kali melemparkan ikan umpan hidup sebagai perangsang agar cakalang lebih mendekat ke kapal sehingga mudah terjangkau oleh pancing-pancing. Pemancing-pemancing cakalang umumnya mempunyai ketrampilan khusus. Kegiatan pemancingan dilakukan begitu rupa yaitu dengan menjatuhkan pancing ke atas permukaan air dan bila disambar oleh cakalang dengan cepat diangkat melalui atas kepala dan secara otomatis terlempar ke dalam dek kapal.

Kegiatan pemancingan dilakukan berulang-ulang dalam tempo yang sangat singkat. Pemancingan dengan cara ini lebih dikenal dengan "cara banting". Disamping itu ada cara memancing yang disebut dengan "cara gepe", yaitu cara pemancingan dengan pole and line dimana setelah ikan terkena pancing dan diangkat dari dalam air kemudian pengambilannya dari mata pancing dilakukan dengan cara menjepit ikan diantara tangan dan badan si pemancing.

7). Faktor Oseanografi yang Mempengaruhi Penyebaran Cakalang

Penyebaran ikan dapat dibedakan menjadi dua macam, yaitu penyebaran horizontal atau penyebaran menurut letak geografis perairan dan penyebaran vertikal atau penyebaran menurut kedalaman perairan (Nakamura, 1969 dalam Simbolon, 2003). Ikan cakalang menyebar luas di perairan tropis dan sub tropis seperti di lautan Atlantik, Samudera Hindia dan Pasifik. Penyebaran ikan tersebut di perairan Indonesia sebagian besar terdapat 
di Kawasan Timur Indonesia (KTI). Stok yang terdapat di perairan KTI ini diduga berasal dari Samudera Pasifik bagian barat yang beruaya dari sebelah timur Philipina dan sebelum utara Papua Nugini. Ikan tersebut selanjutnya beruaya dari perairan KTI ke Samudra Pasafik bagian barat, yaitu ke perairan Zamboanga dan sebelum utara Papua Nugini (Suhendrata, 1987 dalam Simbolon, 2003).

Ikan cakalang secara vertikal dapat menyebar sampai dengan ratusan meter di bawah permukaan air, bahkan banyak terdapat pada kedalaman renang 20 - 200 meter (Nishimura, 1964 dalam Simbolon, 2003). Penyebaran ikan di perairan tropis sangat dipengaruhi oleh lapisan termoklim. Ikan cakalang umumnya ditemukan di atas lapisan termoklim (Laevastu and Hela, 1970 dalam Simbolon, 2003).

Ikan cakalang merupakan ikan pelagis yang membentuk kelompok (schooling). Menurut (Nikolsky, 1963 dalam Simbolon, 2003) individu cakalang dalam suatu schooling mempunyai ukuran (size) yang relatif sama. Ikan-ikan yang berukuran lebih besar biasanya berada pada lapisan yang lebih dalam dengan schooling yang lebih kecil. Ikan-ikan yang lebih kecil biasanya berada dekat permukaan perairan dengan schooling yang lebih besar. Tingkah laku tersebut umumnya dimanfaatkan oleh para nelayan untuk memudahkan penangkapan.

Ikan cakalang melakukan migrasi karena (1) adanya perubahan beberapa faktor lingkungan seperti suhu, salinitas dan arus, (2) usaha mencari daerah perairan yang mengandung bahan makanan yang cukup dan (3) usaha mencari daerah pemijahan (Nikolsky, 1963 dalam Simbolon, 2003). Hal ini sesuai dengan pendapatan Laevastu and Hayes, 1981 dalam Simbolon, 2003) yang menyatakan bahwa pola kehidupan ikan, termasuk cakalang tidak bisa dipisahkan dari pengaruh faktorfaktor oseanografi. Fluktuasi factor-faktor oseanografi seperti suhu, salinitas, arus permukaan, oksigen terlarut mempunyai pengaruh yang besar terhadap periode migrasi musiman serta terdapatnya ikan di suatu lokasi perairan.

\section{8). Salinitas Perairan}

Salinitas perairan merupakan parameter oseanografi yang dapat digunakan untuk memperkirakan daerah penyebaran ikan cakalang di suatu perairan. Kisaran salinitas yang menjadikan daerah penyebaran cakalang umumnya bervariasi menurut wilayah perairan. Cakalang sering terkonsentrasi pada permukaan perairan dengan kisaran salinitas 23\% - 35\% (Blackburn, 1965 dalam Simbolon, 2003). Ikan cakalang mempunyai sifat sensitif terhadap perubahan salinitas. Hal ini terbukti dengan banyaknya ikan cakalang yang ditemukan di perairan ujung timur Selat Sunda ketika salinitas perairannya tinggi. Di lain pihak, ikan cakalang tidak ditemukan sama sekali ketika salinitas rendah (Burhanuddin et al, 1984 dalam Simbolon, 2003).

\section{9). Arus Perairan}

Manurung dan Simbolon (1997), menyatakan bahwa penyebaran ikan pelagis sering mengikuti sirkulasi arus dan kepadatannya sangat berhubungan dengan kondisi arus. Berdasarkan pengamatan yang dilakukan di Selat Makassar, terdapat indikasi bahwa penyebaran berbagi jenis tuna terdapat di sepanjang poros arus. Sepanjang daerah penyebaran tersebut, kelimpahan ikan cenderung lebih banyak pada lapisan renang yang lebih dalam. Ikan cakalang sangat menyenangi daerah pertemuan arus (konvergensi) yang umumnya dijumpai pada wilayah yang memiliki banyak pulau. Turbulansi yang terjadi di perairan sekeliling pulau-pulau atau benua berperan merangsang pertumbuhanplankton. Sebagai konsekuensi logisnya, perairan tersebut relatif lebih subur dan menjadi daerah penyebaran yang baik bagi cakalang untuk mencari makan, seperti halnya di daerah upwelling.

Ikan cakalang sering ditemukan pada perbatasan dua massa air yang berbeda dimana terjadi pertemuan antara massa air panas dan dingin. Daerah ini diduga memiliki berbagai macam organisme dan merupakan daerah penangkapan cakalang yang baik (Laevastu and Hela, 1970 dalam Simbolon, 2003).

10). Suhu Perairan

Suhu perairan secara langsung berpengaruh terhadap derajat metabolisme dan siklus reproduksi ikan. Suhu perairan secara 
tidak langsung berpengaruh terhadap daya larut oksigen yang digunakan untuk respirasi biota laut. Perubahan suhu perairan akan berpengaruh terhadap rangsangan syaraf, perubahan proses metabolisme dan aktivitas tubuh ikan (Laevastus and Hela, 1970 dalam Simbolon, 2003). Kedalaman renang dari kelompok ikan pelagis, termasuk cakalang banyak ditentukan oleh distribusi suhu perairan secara vertikal. Cakalang akan berenang menghindari suhu perairan yang lebih tinggi atau yang lebih rendah dari biasanya dan menuju ke lapisan perairan tertentu di mana ikan tersebut lebih mudah beradaptasi. Distribusi vertikal ikan cakalang di perairan tropis sangat dipengaruhi oleh lapisan termoklin. Adapun kisaran suhu penyebaran dan penangkapan serta lapisan renang dari cakalang dan beberapa jenis tuna disajikan pada Table 2 (Laevastu and Hela, 1970 dalam Simbolon, 2003).

11). Respon Ikan Terhadap Cahaya

Ikan tertarik pada cahaya melalui penglihatan (mata) dan rangsangan melalui otak (pineal region pada otak). Peristiwa tertariknya ikan pada cahaya disebut phototaksis (Ayodhoya, 1976;1981 dalam Malawa dan Sudirman 2004). Ada beberapa alasan mengapa ikan tertarik oleh cahaya, antara lain adalah penyesuaian intensitas cahaya dengan kemampuan mata ikan untuk penerimaan cahaya. Dengan demikian, kemampuan ikan untuk tertarik pada suatu sumber cahaya sangat berbeda-beda. Ada ikan yang senang dengan pada intensitas cahaya yang rendah, tetapi ada pula ikan yang senang terhadap intensitas cahaya yang tinggi. Namun ada ikan yang mempunyai kemampuan untuk tertarik oleh cahaya mulai dari intensitas yang rendah sampai yang tinggi (Sudirman dan Malawa, 2004).

Rangsangan cahaya terhadap ikan diketahui antara 0,01-0,001 lux, sudah memberikan reaksi. Ambang cahaya tertinggi untuk mata ikan belum banyak diteliti, walau banyak diketahui bahwa berbagai jenis ikan laut pada umumnya selalu berusaha untuk meningkatkan sensitifitasnya. Ikan mempunyai suatu kemampuan yang mengagumkan untuk dapat melihat pada waktu siang hari dengan kekuatan penerangan ratusan ribu lux dan dalam keadaan gelap sama sekali (Gunarso, 1985 dalam Sudirman dan Malawa, 2004).

Namun demikian, sensitifitas mata ikan laut pada umumnya tinggi. Kalau cahaya biruhijau yang mampu diterima mata manusia hanya sebesar $30 \%$ saja, tetapi mata ikan mampu menerimanya sebesar $75 \%$ sedangkan retina dari beberapa jenis ikan laut dalam menerimanya sampai $90 \%$. Ambang cahaya yang mampu dideteksi oleh mata ikan jauh lebih rendah daripada ambang cahaya yang dapat dideteksi manusia, sehingga pada umumnya mata ikan mempunyai tingkat sensitifitas 100 kali mata manusia. Oleh sebab itu, pada beberapa jenis ikan yang hidup di perairan pantai dapat mengindera mangsanya dari kejauhan $\mathbf{1 0 0}$ meter sejak pagi sampai sore hari (Gunarso, 1985 dalam Sudirman dan Malawa 2004). Cahaya yang masuk ke mata ikan akan diteruskan ke otak pada bagian Cone dan Rod, yang sangat peka terhadap cahaya. Alasan lainnya, adanya cahaya merupakan suatu indikasi adanya makanan.

Keberadaan sumberdaya kelautan dan perikanan Indonesia adalah amat besar. Sebagai deskripsi, total kekayaan nilai sumber daya kelautan dan perikanan Indonesia diperkirakan sekitar US\$ 136,5 milyar, dan dari jumlah itu, sektor perikanan sebesar US\$ 31,9 milyar, wilayah pesisir lestari sebesar US\$ 56 milyar, bioteknologi laut sebesar US\$ 40 milyar, wisata bahari sebesar US\$ 2 milyar dan minyak bumi sebesar US\$ 6.6 Milyar (Renstra DKP 2004-2009). Namun sayangnya, kesemua sumber daya tersebut belum dimaksimalkan pemanfaatan potensinya. Padahal sektor kelautan dan perikanan tsb dapat menjadi andalan bagi Indonesia sebagai salah satu sumber pertumbuhan ekonomi nasional, penyerapan tenaga kerja dalam jumlah banyak, dan wahana guna meningkatkan kesejahteraan masyarakat Indonesia. Potensi ikan tuna di perairan laut Indonesia khususnya di Kawasan Timur Indonesia (KTI). Dipilihnya ikan tuna karena selain dia masuk kedalam program revitalisasi sektor kelautan dan perikanan bersama udang dan rumput laut, potensi pemanfaatan (tangkapan) ikan tuna di Indonesia, khususnya KTI masih belum maksimal hingga sekarang. 


\subsection{Jenis Ikan Hasil Tangkapan}

Usaha penangkapan dengan pole and line biasanya ditujukan untuk menangkap ikan cakalang (Katsuwonus pelamis) tetapi dalam kenyataannya sering tertangkap juga beberapa jenis ikan yang lain, diantaranya: yellow fin tuna (Thunnus albacares), little tuna (Auxis thazard), dan lain-lain (Balai Ketrampilan Penangkapan Ikan Ambon, 1981). Selanjutnya dalam FAO (1980) mengatakan bahwa para nelayan pole and line terutama menangkap ikan skipjack (Katsuwonus pelamis), albacore (Thunnus alalunga), tuna kecil seperti frigate mackerel (Auxis spp), dan ikan dolphin (Coryphaena spp), juga yellow fin (Thunnus albacares), ikan-ikan muda spesies ikan tuna yang besar yang lain, bonito (Sarda spp), dan tuna kecil (Euthynnus spp). Semua jenis tadi tersebar secara luas di lautan dan Samudera di dunia (Nishida and Martinez, 2007).

\subsection{Penanganan Ikan Hasil Tangkapan}

Cara penanganan yang dipilh umumnya sesuai kondisi yang dikehendaki pasar dengan prinsip yang sama yaitu menjaga mutu ikan agar tetap segar, sehat, aman dan menarik saat disajikan sehingga harganya mampu bersaing saat dipasarkan dan dapat menguntungkan bagi produsennya. Selain itu prinsip penanganan ikan lainnya yang harus dilakukan, antara lain menjaganya dari benturan atau tekanan fisik yang dapat melukai tubuh ikan atau membuat dagingnya memar, melindungi dari sinar panas matahari langsung dan mencegahnya dari kontaminasi bahanbahan yang kotor dan berbahaya. (Prayitno, 2004). Keberhasilan penanganan ikan di atas kapal untuk menjaga mutunya sangat ditentukan oleh:

1) Kesadaran dan pengetahuan semua ABK untuk melaksanakan cara penanganan ikan dengan es secara benar.

2) Kelengkapanpalkah yang berisi es atau peti wadah ikan yang berisolasi dengan kapasitas yang cukup sesuai dengan ukuran kapal.

3) Kecukupan jumlah es yang dibawa saat berangkat menangkap ikan di laut.

Prinsip penanganan ikan di atas kapal untuk ikan ukuran besar (kurang dari 10 kg) menurut Prayitno (2004), adalah sebagai berikut :

1) Ikan-ikan berukuran besar umumnya ditangkap dengan alat tangkap pancing dan biasanya masih dalam keadaan hidup saat diangkat dari air, untuk ini ikan harus segera dibunuh dengan memukul kepalanya atau dengan cara lain yang tidak merusak fisik ikan.

2) Segera mendinginkannya dengan mencelupkan ikan di bakchiling yang telah diisi air es sambil menunggu saat penyiangannya. Suhu air akan selalu terjaga pada suhu $0^{\circ} \mathrm{C}$.

3) Melakukan penyiangan (buang insang dan isi perut, dan untuk ikan-ikan besar juga mengiris sebagianoperculum dan membuang sirip) dan membuang darahnya. Pembersihan dilakukan dengan mencucinya memakai air dingin yang telah didinginkan dengan es.

4) Selanjutnya ikan disusun secara bercampur dan berselang-seling dengan es curah.

Kebijakan Ekpor Ikan Tuna Indonesia ke Luar negeri

Kenaikan rerata volume ekpor tuna/cakalang/tongkol Indonesia ke negaranegara lain selama tahun 2002-2007 adalah 7,26 persen, sedangkan kenaikan rerata untuk tahun 2006-2007 adalah 32,12 persen (lihat tabel 1). Di tahun 2007, misalnya, tercatat 121.316 ton ikan tuna/cakalang/tongkol atau senilai US $\$ 304,3$ juta (DKP 2009) yang diekspor, dan pada tahun itu tercatat 3 negara pengimpor utamanya, yakni Jepang, Amerika Serikat, dan Thailand dapat dilihat pada Tabel 4).

Dari capaian pada Tabel 4, sebenarnya jumlah yang diekspor itu masih di bawah potensi produksi ikan tuna/ cakalang/tongkol yang dihasilkan oleh Indonesia. Untuk diketahui bersama, pada tahun 2007, tercatat 301.531 ton cakalang (skipjack tuna) yang dihasilkan dari berbagai perairan laut di Indonesia (DKP 2007). Di lain sisi, data pada tabel 4 tersebut telah diafirmasi kembali oleh data $F A O$ pada tahun 2009 yang menunjukkan ketersediaan bahan baku tuna Indonesia berlimpah selama kurun waktu 1989-2006 dengan mengalami pertumbuhan sebesar 4,74 persen per tahun. (Kiara, 5 April 2009). Pertanyaan yang timbul 
dari kita adalah: apakah pertumbuhan 4,74 $\exists$ persen per tahun itu sudah menunjukkan maksimal pemanfaatan potensi ikan tuna dan cakalang yang berada di perairan laut Indonesia? Jika belum, bagaimana cara kita meningkatkan (produksi) tangkapan ikan tuna dan cakalang.

2.7. Sumberdaya Perikanan Belum dimanfaatkan Secara Maksimal

Kawasan Timur Indonesia (KTI) adalah zona perairan laut Indonesia yang menyimpan keragaan dan kekayaan sumberdaya ikan laut yang besar. Namun, tingkat pemanfaatan dari potensi yang tersedia adalah masih relatif rendah sebagaimana tampak pada Tabel 5 .
Berdasarkan Tabel 5, diketahui bahwa di Kawasan Timur Indonesia, pemanfaatan potensi perikanan laut belum maksimal. Sebagai contoh, pemanfaatan ikan jenis tuna masih di bawah $80 \%$. Hal sama juga terjadi untuk ikan tongkol, dimana di laut Arafuru (sekitar 93\%), laut Banda $(82 \%)$, dan laut Sulawesi $(80 \%)$ adalah potensi yang belum dirmanfaatkan (Departemen Koperasi dan UMKM, 2007). Padahal di kawasan laut Arafuru, laut Banda, laut Sulawesi, laut Maluku, dan lautan Hindia masih kaya potensi ikan laut seperti ikan tuna, tongkol, pelagis kecil, cakalang, dan tenggir (Anonimous, 2007).

Tabel 4. Volume Ekspor Tuna dan Cakalang Menurut Negara Tujuan, 2002 - 2007 (sebagian data).

\begin{tabular}{ccccccccc}
\hline $\begin{array}{l}\text { Negara } \\
\text { Tujuan }\end{array}$ & \multicolumn{9}{c}{ Tahun } & \multicolumn{3}{c}{ Increasing Average } \\
\cline { 2 - 9 } & 2002 & 2003 & 2004 & 2005 & 2006 & 2007 & $2002-2007$ & $2006-2007$ \\
\hline Japan & 41149 & 34173 & 34715 & 30257 & 30998 & 31330 & 4,94 & 1,07 \\
USA & 14134 & 20345 & 19270 & 21773 & 21212 & 21375 & 9,97 & 0,77 \\
Thailand & 3696 & 3501 & 1288 & 958 & 4621 & 18849 & 119,22 & 307,92 \\
Negara & 1755 & 2478 & 109 & 3222 & 9511 & 13098 & 82,70 & 37,72 \\
Lainnya & & & & & & & \\
\hline Jumlah Total & 92797 & 117092 & 94221 & 90589 & 91822 & 121316 & 7,26 & 32,12 \\
\hline
\end{tabular}

Sumber :http://statistik.dkp.go.id/download/Statistik, 2007

Tabel 5. Tingkat Pemanfaatan (\%) Sumberdaya Ikan Laut Indonesia

\begin{tabular}{|c|c|c|c|c|c|c|c|}
\hline Wilayah Perairan & Udang & Demersal & Pelagis kecil & Tuna & Skipjack & Tenggiri & Tongkol \\
\hline Selat Malaka & 154 & 178 & 106 & & & & \\
\hline Laut Cina Selatan & 114 & 30 & 23 & & & & \\
\hline Laut Jawa & 161 & 54 & 132 & & & 46 & 114 \\
\hline Laut Flores & 106 & 103 & 50 & 76 & 107 & 37 & 78 \\
\hline Laut Banda & No data & 56 & 25 & 42 & 38 & 14 & 18 \\
\hline Laut Maluku & 68 & 76 & 46 & 64 & 37 & 7 & 63 \\
\hline Laut Sulawesi & 116 & 100 & 29 & 58 & 25 & 102 & 20 \\
\hline Laut Arafuru & 98 & 93 & 4 & 52 & 70 & 26 & 7 \\
\hline Lautan Hindia & 88 & 84 & 41 & 38 & 19 & 29 & 58 \\
\hline
\end{tabular}

Sumber: DKP (diolah) sebagaimana dicuplik dari Departemen Koperasi dan UMKM (2007).

\subsection{Strategi Untuk Meningkatkan Produksi} Tangkapan Ikan Tuna dan Cakalang

Guna meningkatkan produksi tangkapan ikan tuna dan cakalang, Indonesia telah menempuh sejumlah cara. Cara pertama yang telah ditempuh adalah dengan menjadi salah satu anggota organisasi ikan tuna pada level regional, dan cara ke dua, yaitu dengan memperbarui peralatan dan perlengkapan untuk menangkap ikan. Cara pertama dianggap efektif dan efisien guna meningkatkan hasil tangkapan (produksi) ikan tuna Indonesia Mengapa cara pertama tersebut ditempuh oleh Indonesia.

Hal ini karena dengan menjadi anggota, maka para nelayan Indonesia akan mendapatkan hak legal untuk memperluas daerah tangkapan ikan tuna dan mereka dapat melaut hingga ke Samudra Hindia. Untuk yang terakhir ini, Indonesia mendapatkan hak itu setelah dia menjadi anggota komisi tuna untuk kawasan Samudra Hindia (Indian Ocean Tuna 
Commision, IOTC) dan komisi konservasi tuna sirip biru (Commision for The Conservation of Southern Bluefin Tuna, CCSBT).

Adapun untuk saat ini, Indonesia sedang menjajaki peluang menjadi anggota organisasi ikan tuna Pasifik Barat dan Tengah (Western and Central Pacific Fisheries Commission/WCPFC). Maksudnya, dengan menjadi anggota pada WCPFC, maka nelayan Indonesia dapat memperluas daerah tangkapan tuna hingga ke wilayah Pasifik (Achmad Poernomo, April 2009). Di samping itu, dengan menjadi anggota pada salah satu organisasi ikan tuna regional, maka hal itu akan memberikan peluang Indonesia memiliki kuota penangkapan dan menghindarkan Indonesia dari kemungkinan embargo produk tuna dan tuduhan kapal Indonesia melakukan praktek IUU fishing (Renstra DKP 2005-2009).

Adapun cara ke dua dilakukan Indonesia melalui sejumlah cara. Diantaranya adalah dengan memperbaharui alat tangkap ikan modern beserta kapal penangkap ikan modern, diberikannya subsidi BBM dari pemerintah untuk sektor kelautan dan perikanan sehingga para nelayan mendapatkan insentif cukup untuk menjala ikan tuna hingga ke daerah perairan/ laut terjauh, serta pelatihan-pelatihan bagi para nelayan agar hasil tangkapan ikan tuna meningkat tanpa merusak ekosistem laut dan perairan di sekitar area penangkapan.

\section{PENUTUP}

3.1. Kesimpulan

- Sumberdaya ikan yang tersedia cukup melimpah namun diperlukan ketrampilan dan pengelolaan sumberdaya dengan mempertimbngkan berbagai aspek-aspek yang harus yaitu aspek teknologi, sumberdaya manusia, bio-teknologi, aspek sosial dan aspek ekonomi.

- Untuk mengelola sumberdaya ikan tuna dan cakalang dengan baik diperlukan manajamen untuk mengadakan koordinasi dengan sejumlah aktivitas yang meliputi Planning, Organizing, Actuating, dan Controlling

- Untuk mendapatkan hasil tangkapan yang melimpah maka perlu diperhatikan aspek oseonografi yang meliputi, salinitas, $\mathrm{pH}$, arus, suhu perairan dan alat tangkap yang tepat untuk mendapatkan ikan.

- Volume ekspor tuna dan cakalang terus meningkat dibeberapa negara yaitu Jepang, Amerika Serikat, China dan Thailand namun untuk mendukung hal tersebut diperlukan daya dukung yang serius dari pemerintah.

\subsection{Saran}

- Perlu dilakukannya penyuluhan tentang pengelolaan sumberdaya ikan yang baik yang ramah lingkungan dan tidak dilakukan penangkapan pada saat ikan mulai memijah sehingga sumberdaya ikan terus berkesinambungan dari waktu ke waktu.

- Perhatian pemerintah yang lebih berupa bantuan peralatan dan modal kerja sehingga dengan sendirinya taraf hidup keluarga nelayan lebih meningkat.

- Perlu dilakukannya penanganan ikan yang baik mulai pada saat penangkapan, penyimpanan di kapal, pendaratan sampai pada distribusi sehingga produk ekspor cakalang dan tuna terus meningkat dari tahun ke tahun.

\section{DAFTAR PUSTAKA}

Anonimous, 2011. Pendataan dalam Rangka Revitalisasi Perikanan Tuna. Jakarta

Anonimous, 2004. Undang-Undang Republik Indonesia No. 32 Tahun 2004 tentang Pemerintah Daerah, Jakarta.

Anonimous, 2004. Undang-Undang Republik Indonesia No. 31 Tahun 2004 tentang Perikanan, Jakarta.

Anonimous, 2007. Direktorat Kelautan dan Perikanan Republik Indonesia, Jakarta.

Statistik , 2007.Departemen Kelautan dan Perikanan Republik Indonesia, Jakarta.

Anonimous, 2011, Manajemen Perikanan tangkap, Sekolah Tinggi Perikanan. Pasar Minggu, Jakarta. 
Anoraga, P. dan Sudantoko, D. 2002. Koperasi, Kewirausahaan, dan Usaha Kecil. Jakarta : Rineka Cipta.

Assauri, Sofyan. 1999. Manajemen Produksi dan Operasi. Edisi revisi Penerbit LPFE UI Jakarta.

Direktorat Jenderal Perikanan Departemen Pertanian. 1999. Kajian Kebutuhan Investasi Pembangunan Perikanan dalam Pembangunan Lima Tahun Mendatang.

Dedi Makur, 2004. Sosialisasi Nasional Program MFCDP, Deputi Menteri Negara Perencanaan Pembangunan Nasional Kepala Bappenas Bidang Sumberdaya Alam dan Lingkungan Hidup, Jakarta.

Dahuri, 2004. Membangun Indonesia yang Maju Makmur dan Mandiri Melalui Pembangunan Kemaritiman, Makalah Temu Nasional, Visi, Misi Maritim Indonesia dari Sudut Pandang Politik Jakarta.

Dahuri, Rais, Ginting, Sitepu 2001. Pengelolaan Sumberdaya Wilayah Pesisir dan Lautan Secara Terpadu. Pradnya Paramita, Jakarta.

马irektorat Jenderal Perikanan Tangkap DKP, 2005. Undang-Undang RI nomor 31 Tahun 2004 Tentang Perikanan, Jakarta

Hasibuan, 2002. Manajemen Sumberdaya Manusia. Edisi Revisi, Penerbit Bumi Aksara, Jakarta.

Handoko, 2000. Manajemen Personalia dan Sumberdaya Manusia. Penerbit PT.BPFE.Yogyakarta.

Mallawa, 2006. Lokakarya Agenda Penelitian Program COREMAP II, Kabupaten Selayar 9-10 Sepetember 2006.

Manullang, 2001. Manajemen Personalia Edisi 3. Edisi I, Yogyakarta: BPEE

Nishida and Martinez, 2007. FAO. Scientific Update on Carbohydrates in Human Nutrition European Journal of Clinical Nutrition

Rafik, 2011. Artikel Perikanan Tangkap, Dunia Kelautan dan Perikanan, Jakarta

Siswanto, 2005. Manajemen Tenaga Kerja Indonesia Pendekatan administratif dan Oprasional, Bumi Akasara. Jakarta.

Sudirman dan Mallawa, 2004. Teknik Penangkapan ikan. Penerbit Rineka Cipta. Jakarta

Terry, 2003. Dasar-dasar Manajemen, PT Bumi Aksara. Jakarta.

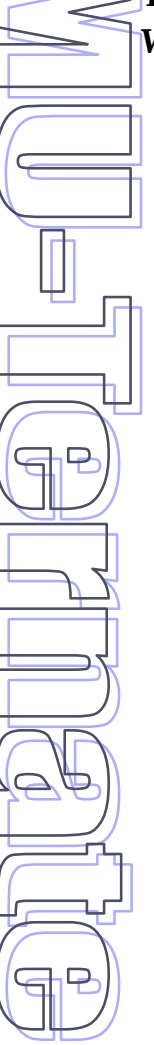

Winardi, 1979. Pengantar Metodologi Riset. Bandung, Jawa Barat. 